\title{
Diallel analysis of upland cotton cultivars
}

\author{
Paulo Antonio de Aguiar ${ }^{*}{ }^{*}$, Júlio Cesar Viglioni Penna ${ }^{2}$, Eleusio Curvelo Freire ${ }^{3}$, and Leonardo Cunha Melo ${ }^{4}$
}

Received 08 January 2007

Accepted 10 August 2007

\begin{abstract}
Crosses involving eight commercial upland cotton cultivars were performed in all possible combinations to generate 28 hybrids. The eight parental genotypes were also evaluated. A field experiment was conducted using a triple Latice design (6x 6) in Itumbiara, Brazil, during the 2000/01 growing season. Data of the following agronomic and fiber traits were collected: seedcotton yield, lint yield, seed index, picked lint percent, index of production and earliness, micronaire index, fiber strength, fiber length, uniformity index, short-fiber index, fiber elongation, CSP index, reflectance and yellowness and used in the analysis of variance as proposed by Griffing (1956), method 4. Significant differences were detected among treatments and the estimates of combining abilities. Additive gene action prevailed for most traits studied. Both positive and negative heterotic values were detected, demonstrating the potential of hybrid combinations for trait improvement in breeding programs.
\end{abstract}

Key words: Gossypium hirsutum, combining ability, heterosis.

\section{INTRODUCTION}

Plant breeding deals essentially with selection of superior individuals within genetically heterogeneous populations. The basic objective of autogamous breeding programs is the establishment of pure lines of high economic value selected out of segregating populations. In the particular case of cotton (Gossypium hirsutum L.), genotypes are sought that meet the needs of three sectors of the economy: cotton growers, the ginning mills and the textile complex. The populations used for selection may be land races, introduced (exotic) germplasm or products of the crossing of selected genotypes. In such crossings, favorable allele combinations are expected to originate new commercial cultivars highly adapted to cotton-growing regions. Some phases in this process are of paramount importance, such as: selection of parents with identification of the best hybrid combinations; the advance of generations without the loss of favorable gene combinations and finally the selection of pure superior lines with maximum experimental precision. For success in the entire selection procedure, plant breeders rely on the soundness of estimates of genetic parameters that represent the concentration of favorable alleles in the parental genotypes and their hybrid combinations. In this context diallel crosses are of great value, since they provide information about parental genotypes and the segregating generations that follow crosses between them.

The analyses of diallel crosses contain further information on the nature of the predominant gene action in traits of major agronomic importance, besides estimates of general (GCA) and specific combining ability (SCA). The GCA indicates parental behavior in hybrid

\footnotetext{
${ }^{1}$ Departamento de Agronomia (ILES/ULBRA), Avenida Beira Rio, 1001, 75.523-200, Itumbiara, GO, Brasil. *E-mail: aguiar_itb@yahoo.com.br

${ }^{2}$ Universidade Federal de Uberlândia (UFU), ICIAG, Uberlândia, MG, Brasil

${ }^{3}$ Embrapa Algodão, Campina Grande, PB, Brasil

${ }^{4}$ Embrapa Arroz e Feijão, Goiânia, GO, Brasil
} 
combinations and is associated mainly with the additive gene effects, although it also depends on genes with dominance and additive $\mathrm{x}$ additive epistatic effects. SCA defines the specific behavior of a hybrid combination relative to the parental average and depends largely on dominant gene effects and dominant $\mathrm{x}$ dominant epistatic effects (Sprague and Tatum 1942).

The identification of these parameters lets breeders concentrate their efforts on hybrid populations potentially capable of producing superior progenies, facilitating the selection of pure lines. Among the different commonly used methods of choosing parents and identifying promising hybrid combinations, Griffing (1956) made a noteworthy proposal. In this method the sums of squares for the effects of general and specific combining ability are estimated as well as the effects themselves.

This study aimed to evaluate the general and specific combining ability and heterosis and to discover information on the genetic control of agronomic and fiber traits in the hybrid combinations obtained by all possible crosses of eight selected upland cotton cultivars.

\section{MATERIAL AND METHODS}

During the growing season of 2000/01, eight cotton (Gossypium hirsutum L.) cultivars (Ita-90 ; Ita-96 ; Antares ; Alva ; CD-403 ; DeltaOpal ; CS-50 and IAC 22) together with their $28 \mathrm{~F}_{1}$ hybrid combinations were evaluated in an experimental area of the Agronomy Department of the Universidade Luterana do Brasil, in Itumbiara, state of Goias, Brazil. The experimental design was a 6 x 6 Lattice with three replications. Plots comprised two four-meter rows each, with an average of 72 plants after thinning. Data were collected from each plot to determine the following variables: seedcotton yield - SY $\left(\mathrm{g} \mathrm{plot}^{-1}\right)$; picked lint percent - PLP (\%); lint yield - LY $\left(\mathrm{g} \mathrm{plot}^{-1}\right)$; seed index - SI $(\mathrm{g})$; micronaire index - MI $\left(\mu \mathrm{g} \mathrm{pol}{ }^{-1}\right)$, fiber strength FS (gf/tex); fiber length - FL (mm), uniformity index - UNI (\%); short fiber index - SFI, fiber elongation - FE (\%); CSP (Count Strength Product) index; fiber reflectance - FR, yellowness " $b$ " - Yb and index of production and earliness - IPE. With exception of seedcotton yield and index of production and earliness, all other traits were determined based on a twenty-boll sample taken randomly from the mid-section of the plants. The analysis of variance was applied to Griffing (1956) model 4. Only the F1 hybrids were used to estimate the general and specific combining ability, while both parents and hybrids were used to estimate heterosis. The model was considered fixed since the cultivars used were deliberately selected and therefore represent the final population on which valid conclusions should be drawn (Griffing 1956). The analysis of variance was performed in two stages: first each trait was analyzed individually (intrablock analysis with recovery of interblock information) according to the Lattice design, Cochran \& Cox (1957). In a second stage, adjusted treatment means and replications were utilized for the combining ability variance analysis, i.e., the sum of squares for treatments was partitioned into general and specific combining ability. The effective mean square Lattice was used as residual error. The statistical model for the combining ability analyses was:

$$
\begin{aligned}
& Y_{i j}=m+g i+g j+s i j+\text { Eij, where: } \\
& \text { Yij= mean value of hybrid } i j(i, j=1,2, \ldots \ldots . . p, i<j) ; \\
& m=\text { overall mean; } \\
& \text { gi, gj = effects of the general combining ability of }
\end{aligned}
$$
the combination of $i^{\text {th }}$ and $j^{\text {th }}$ parent, respectively;

$s i j=$ effect of the specific combining ability for crosses between parentals of the $i$ and $j$ order;

Eij = experimental error;

It was considered that $\mathrm{sij}=\mathrm{sji}$

Besides the combining ability effects, heterosis values were estimated and expressed as $F_{1}$ deviations from both parents, as percent.

\section{RESULTS AND DISCUSSION}

The analysis of variance of the diallel (Table 1) indicated that, with exception of the traits fiber length (FL), short fiber index (SFI) and fiber reflectance, all other traits presented variability among treatments. The treatment sums of squares was partitioned into general and specific combining ability. As expected, with exception of the above-cited, the GCA estimates $(\mathrm{P}<0.01)$ of all traits were statistically significant. This indicates that at least one parent was superior to the others, regarding the mean performance in hybrid combinations. For SCA, significant effects were found for the traits seedcotton yield, lint yield, seed index and index of production and earliness, which indicates that the hybrid combinations differed from each other. For the respective above traits, the additive gene effects accounted for $57,53,71$ and $44 \%$ of the total genetic effects.

The predominance of quadratic effects associated to the GCA for all traits under study was also verified, with exception of the index of production and earliness, as demonstrated by the value obtained for the proportions GCA/SCA+GCA (Table 1). Similar results 


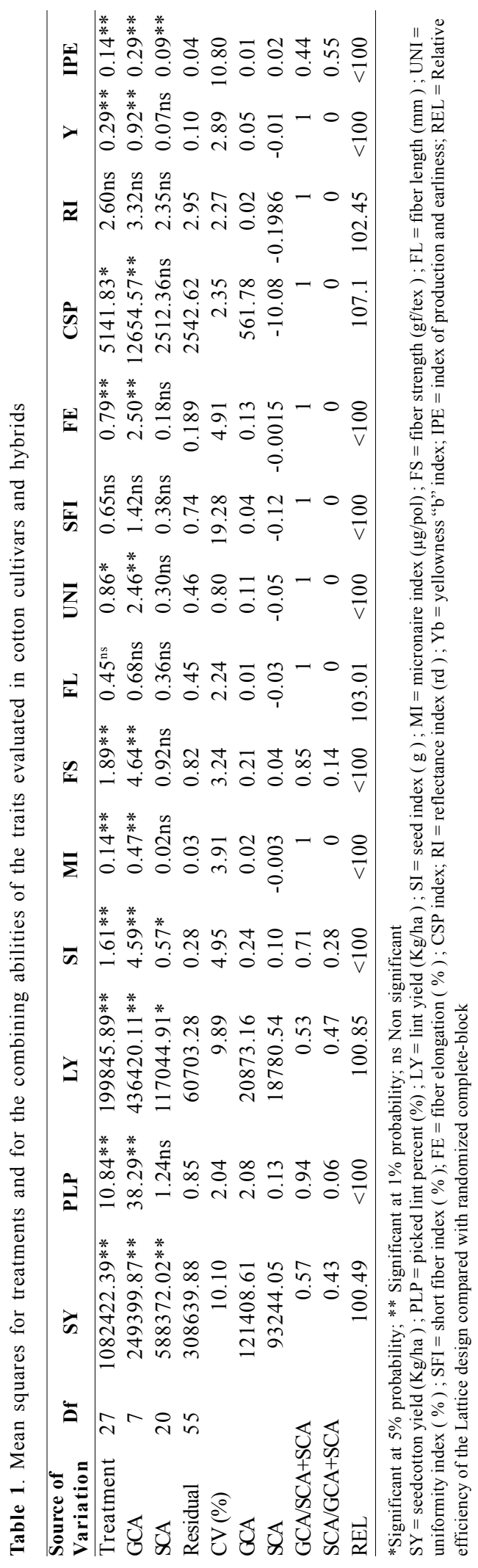

were obtained by Verma et al. (1988), Costa et al. (1977), Sobral et al. (1991), Carvalho et al. (1995), Coyle and Smith (1997) and Pedrosa (2001).

\section{General combining ability effect estimates $-g_{i}$}

Table 2 presents the general combining ability effects (gi) for traits evaluated for each genotype, as well as the standard deviations of the estimates. For the cultivars IAC-22, Antares and CD-403 the traits seedcotton yield (SY), lint yield (LY), seed index (SI) and index of production and earliness (IPE), presented positive and significant gi values, which indicates superior average performance over the other parents in the crosses they participated in. For SY, cultivar IAC-22 presented the greatest yield increment in relation to the other parents, although it differed significantly only in relation to CD-403. For the traits LY and IPE, IAC-22 contributed with greater absolute values, but was not significantly different from Antares and CD-403). As for SI, IAC 22 presented values significantly higher values than the others.

The index of production and earliness (IPE) evaluates the real precocity of plants since it takes both production and earliness into account. Earliness is only preferable when associated to higher yields. The partitioning of the treatment sum of squares for IPE indicated both additive and non-additive effects on the genetic control with predominance of non-additive genetic variance. Similar results were found by Carvalho (1995).

The positive and significant estimates of general combining ability (gi) of cultivars CS-50, DeltaOpal and Ita-90 were highest when only picked lint percent was considered which indicates that these genotypes are the best parents in comparison to the others included in the diallel. CS-50 differed significantly from the other cultivars. The increments for the trait in question promoted by the respective parents cited above were $2.08,1.17$ and $1.06 \%$, which indicates them for improvement of this trait. On the other hand, the gi estimates for seed index of these same genotypes were low and negative, which indicates a negative relationship between the two traits.

CD-403 was the only cultivar with a positive GCA estimate for the agronomic traits under evaluation (SY, PLP, LY, SI and IPE), although for PLP, SI and SY this genotype did not perform better than the other parents in the diallel. Therefore, cultivar CD-403 may be indicated for the improvement of these traits. 
Table 2. Estimates of the general combining ability effects of the traits evaluated for cotton cultivars and hybrids

\begin{tabular}{lrrrrrrrrrrr}
\hline Parentals & \multicolumn{1}{c}{ SY } & \multicolumn{1}{c}{ PLP } & \multicolumn{1}{c}{ LY } & \multicolumn{1}{c}{ SI } & \multicolumn{1}{c}{ MI } & \multicolumn{1}{c}{ FS } & \multicolumn{1}{c}{ UNI } & \multicolumn{1}{c}{ FE } & \multicolumn{1}{c}{ CSP } & Y & \multicolumn{1}{c}{ IPE } \\
\hline Ita-90 & -442.95 & 1.06 & -131.00 & -0.26 & 0.14 & -0.05 & -0.02 & -0.012 & -13.42 & -0.02 & -0.15 \\
Alva & -529.13 & 0.29 & -223.05 & 0.19 & -0.24 & -0.19 & -0.64 & -0.72 & 30.42 & -0.34 & -0.11 \\
Antares & 387.17 & -1.18 & 102.33 & 0.16 & -0.26 & 0.17 & -0.44 & -0.18 & 32.42 & -0.03 & 0.14 \\
CD-403 & 227.07 & 0.11 & 110.21 & 0.27 & 0.07 & -0.53 & 0.08 & 0.23 & -19.42 & 0.03 & 0.08 \\
CD-50 & -38.13 & 2.08 & 96.94 & -0.78 & 0.05 & 0.41 & 0.06 & -0.12 & 11.08 & -0.26 & 0.01 \\
DeltaOpal & 106.50 & 1.17 & 107.07 & -0.45 & 0.01 & 0.98 & 0.35 & 0.09 & 9.08 & 0.06 & 0.06 \\
IAC-22 & 489.37 & -1.35 & 138.14 & 0.88 & 0.07 & -0.37 & 0.45 & 0.38 & -3.58 & 0.23 & 0.15 \\
ITA-96 & -199.91 & -2.18 & -200.62 & 0.16 & 0.15 & -0.43 & 0.14 & 0.43 & -46.58 & 0.34 & -0.16 \\
\hline DP(Gi) & 122.49 & 0.20 & 54.32 & 0.12 & 0.04 & 0.20 & 0.15 & 0.10 & 11.12 & 0.07 & 0.04 \\
\hline DP(Gi-Gj) & 185.18 & 0.31 & 82.13 & 0.18 & 0.06 & 0.30 & 0.23 & 0.15 & 16.81 & 0.11 & 0.07 \\
\hline
\end{tabular}

$\mathrm{SD}$ : standard deviation; $\mathrm{SY}=$ seedcotton yield $\left(\mathrm{kg} \mathrm{ha}^{-1}\right) ; \mathrm{PLP}=$ picked lint percent $(\%) ; \mathrm{LY}=\operatorname{lint}$ yield $\left(\mathrm{kg}\right.$ ha $\left.{ }^{-1}\right) ; \mathrm{SI}=\mathrm{seed}$ index $(\mathrm{g}) ; \mathrm{MI}=$ micronaire index $; \mathrm{FS}=$ fiber strength $(\mathrm{gf} / \mathrm{tex}) ; \mathrm{UNI}=$ uniformity index $(\%) ; \mathrm{FE}=$ fiber elongation $(\%) ; \mathrm{CSP}$ index; $\mathrm{Y}=\mathrm{yellowness}$ "b" index; $\mathrm{IPE}=$ index of production and earliness

Significant and positive gi values demonstrate the importance of genes of additive action, because they induce higher gains through selection and may be eventually fixed. As far as fiber traits were concerned, the treatment sums of squares, as well as their partitioning (Table 1) were not significant for fiber length (FL), short fiber index (SFI) and reflectance index (RI). This indicates, at least for these traits, the similarity of the cultivars used. With respect to the micronaire index, breeders seek genotypes with around-mean GCA estimates (gi), since moderately finer fibers are desired. The most negative value was found for cultivar Antares $(-0.26)$, followed by Alva (-0.24), with no significant difference between them. The fiber strength of Antares was also high, which indicates the cultivar for the improvement of both characters. Antares further presented the highest gi value for the CSP, which is an overall indicator of spinning ability.

IAC-22 is the cultivar indicated for the improvement of both uniformity index and fiber elongation, owing to the high, positive and significant gi values.

\section{Specific combining ability effect estimates - Sij}

The estimates of the effects of specific combining ability (Sij) and parental heterosis (\%) for the agronomic traits are displayed in Table 3. The hybrid combinations with the greatest significant and positive SCA (Sij) estimates for traits SY, LY and IPE, were DeltaOpal x ITA-96, DeltaOpal x IAC-22, Ita-90 x Antares and Ita-90 $x$ CD-403. It is worth mentioning that these crosses involve parents with highest GCA estimates (IAC-22, Antares, CD-403 and DeltaOpal), so their use is indicated to improve the cited traits (Ramalho et al. 1993). When the above hybrid combinations including a common parental are compared, or even combinations without a common parent, it is verified that they do not significantly differ among each other. The SCA of the combinations CS-50 x DeltaOpal, CD-403 x IAC-22, ITA$90 \times$ ITA-96 and Antares x DeltaOpal was high and negative, indicating the existence of inherent undesirable gene interactions.

The best hybrid combinations for SI, as evidenced by their high and significant SCA estimates, were: Alva x DeltaOpal, DeltaOpal x IAC-22, Ita-90 x Antares, Ita-90 $x$ DeltaOpal, Alva x CD-403 and Alva x CS-50. In the comparison of the hybrid combinations with and those without a common parent, no significant differences were found. The hybrids Alva x DeltaOpal, DeltaOpal x IAC-22, Ita-90 x Antares and Alva x CD-403, are recommended for SI improvement since they involve at least one parent with a high SCA estimate. Both parents of hybrid Alva x CD-403 presented high SCA estimates. The combinations Ita- $90 \mathrm{x}$ Antares and DeltaOpal $\mathrm{x}$ IAC22 are indicated for the improvement of SY, LY, SI and IPE, since the SCA estimates were high, positive and significant besides involving one parent that obtained high, positive and significant SCA estimates.

The trait IPE showed superiority for the quadratic component associated to SCA in relation to the total variation for this character, as indicated by the value obtained for the proportion SCA/ SCA + SGA. According to Cruz and Regazzi (1997), this is the result of selection that tends to reduce additive effects and in turn increases the importance of non-additive variation.

The SCA effects of the six fiber properties that showed variability among treatments (MI, FS, UNI, FE, CSP and Y) were not significant (Table 1). 
PA Aguiar et al.

Table 3. Estimates of the effect of specific combining ability (sij) and parental heterosis (\%)

\begin{tabular}{|c|c|c|c|c|}
\hline Hybrid Combinations & SY & LY & SY & IPE \\
\hline Ita 90 x Alva & $-120.0(10.6)^{*}$ & $-71.56(8.90)$ & $-0.2467(7.8)$ & $-0.600(13.9)$ \\
\hline Ita $90 \times$ Antares & $600.6(21.5)$ & $288.60(19.35)$ & $0.4533(10.8)$ & $0.2543(29.5)$ \\
\hline Ita $90 \times$ CD-403 & $415.1(19.2)$ & $201.58(15.39)$ & $0.1700(5.6)$ & $0.2210(26.9)$ \\
\hline Ita $90 \times$ x CS-502 & $10.0(7.7)$ & $132.38(7.36)$ & $-0.4433(2.7)$ & $0.0963(15.8)$ \\
\hline Ita 90 x Delta Opal & $-125.9(4.2)$ & $-95.01(1.28)$ & $0.3933(6.8)$ & $-0.0982(3.3)$ \\
\hline Ita 90 x IAC 22 & $-397.8(8.4)$ & $-187.11(7.08)$ & $-0.2783(3.0)$ & $-0.1894(6.5)$ \\
\hline Ita 90 x ITA 96 & $-582.1(-1.3)$ & $-268.88(-2.85)$ & $-0.0483(0.0)$ & $-0.2239(-0.5)$ \\
\hline Alva x Antares & $-261.3(12.6)$ & $-161.96(8.53)$ & $-0.1633(6.5)$ & $-0.1370(15.7)$ \\
\hline Alva x CD-403 & $290.1(23.5)$ & $115.44(21.46)$ & $0.3933(9.5)$ & $0.0946(29.8)$ \\
\hline Alva x CS-50 & $379.1(20.0)$ & $164.84(17.56)$ & $0.2800(12.6)$ & $0.1330(28.8)$ \\
\hline Alva x Delta Opal & $-18.1(14.9)$ & $-18.56(13.10)$ & $0.6167(10.9)$ & $0.0235(20.4)$ \\
\hline Alva x IAC-22 & $157.5(298)$ & $112.21(32.25)$ & $-0.3850(3.8)$ & $0.0763(34.1)$ \\
\hline Alva x ITA-96 & $-427.3(11.3)$ & $-140.41(13.98)$ & $-0.4950(-2.3)$ & $-0.1302(18.1)$ \\
\hline Antares x CD-403 & $-110.8(10.9)$ & $-54.97(8.03)$ & $0.2533(4.5)$ & $-0.0710(15.2)$ \\
\hline Antares x CS-50 & $75.8(9.8)$ & $47.70(7.29)$ & $0.1400(6.8)$ & $0.0113(16.7)$ \\
\hline Antares x Delta Opal & $-490.7(2.30)$ & $-158.62(2.38)$ & $-1.0233(-8.8)$ & $-0.1412(7.6)$ \\
\hline Antares x IAC-22 & $164.5(23.2)$ & $83.84(22.12)$ & $-0.0250(3.6)$ & $0.0426(26.2)$ \\
\hline Antares x ITA-96 & $21.9(16.7)$ & $-44.58(12.11)$ & $0.3650(2.2)$ & $0.0411(25.0)$ \\
\hline CD-403 x CS-50 & $-158.9(4.50)$ & $-101.94(1.38)$ & $-0.1333(1.7)$ & $-0.0740(10.9)$ \\
\hline CD-403 x Delta Opal & $162.1(13.30)$ & $71.35(11.19)$ & $-0.4667(-5.4)$ & $0.0635(17.9)$ \\
\hline CD-403 x IAC-22 & $-607.2(8.00)$ & $-247.82(7.82)$ & $-0.2983(-0.7)$ & $-0.1957(11.7)$ \\
\hline CD-403 x ITA & $-969.6(15.20)$ & $16.36(14.6)$ & $0.0817(-2.2)$ & $-0.0382(18.9)$ \\
\hline CS-50 x Delta Opal & $-824.4(-9.70)$ & $-358.36(-9.70)$ & $-0.0800(0.8)$ & $-0.3272(-7.1)$ \\
\hline CS-50 x IAC-22 & $27.3(15.2)$ & $3.59(13.07)$ & $0.2583(7.2)$ & $0.0256(21.3)$ \\
\hline CS-50 x ITA-96 & $291.1(16.2)$ & $111.79(13.19)$ & $-0.0217(-0.8)$ & $0.1351(26.8)$ \\
\hline Delta Opal x IAC-22 & $633.0(29.7)$ & $234.38(26.23)$ & $0.5850(5.9)$ & $0.2521(33.0)$ \\
\hline Delta Opal x ITA-96 & $664.2(26.9)$ & $324.81(26.77)$ & $-0.0250(-4.5)$ & $0.2276(31.4)$ \\
\hline IAC-22 x ITA -9 & $622.7(23.9)$ & $0.91(24.01)$ & $0.1433(0.0)$ & $-0.0115(26.1)$ \\
\hline $\mathrm{SD}(\mathrm{sij})$ & 271.0 & 120.22 & 0.2591 & 0.0976 \\
\hline $\mathrm{SD}(\mathrm{sij}-\mathrm{sik})$ & 414.0 & 183.64 & 0.3958 & 0.1491 \\
\hline$\overline{\mathrm{SD}}(\mathrm{sij}-\mathrm{skl})$ & 370.4 & 164.25 & 0.3540 & 0.1333 \\
\hline
\end{tabular}

* Heterosis of crosses (\%) SY - seedcotton yield $\left(\mathrm{kg} \mathrm{ha}^{-1}\right) \quad$ LY-lint yield $\left(\mathrm{kg} \mathrm{ha}^{-1}\right) \quad$ SI- seed index IPE- index of production and earliness

\section{Heterosis}

Heterosis or hybrid vigor is the increment in performance of a hybrid (F1 generation) in relation to the parental average and can assume positive or negative values. Table 3 displays the heterosis values in percent (in parentheses) for the agronomic characters evaluated.

\section{Seedcotton yield (SY)}

Among the 28 hybrid combinations, only two presented negative SY values, CS-50 x DeltaOpal (-9.70 $\%$ ) and ITA-90 x ITA-96 (-1.3\%). The heterosis values of all others ranged from 2.30 to $29.8 \%$. The three combinations with the highest heterotic values were
DeltaOpal x ITA-96 (26.9\%), DeltaOpal x IAC-22 (29.7 $\%)$ and Alva x IAC-22 (29.8\%). Interestingly the first two hybrids also presented the highest and positive SCA estimates.

\section{Lint Yield (LY)}

The heterotic values for this trait were similar to those for seedcotton yield and the same two hybrid combinations presented negative estimates: CS-50 x DeltaOpal (-9.70\%) and ITA-90 x ITA-96 (-2.85\%), while positive heterosis varied from 1.28 to $32.25 \%$ for the other crosses. Again, the three combinations which presented the highest heterosis values were DeltaOpal x IAC-22 (26.23\%), DeltaOpal x ITA-96 (26.77\%) and Alva x IAC-22 (32.25\%). 


\section{Seed Index (SI)}

For this character the majority of the crosses presented positive heterotic responses with exception of seven that presented negative values (varying from -0.7 to $-8.8 \%$. The positive estimates ranged from 0.84 to $12.6 \%$, the latter corresponding to the cross Alva $\mathrm{x}$ CS-50. Both the GCA and SCA estimates of this hybrid were positive and significant for the parent Alva as well, which recommends it for trait improvement. No heterosis was found in the hybrid combinations IAC22 x ITA-96 and ITA-90 x Ita 96.

\section{Index of Production and Earliness (IPE)}

Crosses CS-50 x DeltaOpal and ITA-90 x ITA-96 presented negative estimates for this trait $(-7.1 \%$ and $0.5 \%$ respectively), while the values of all other combinations were positive (ranging from 3.3 to $33.0 \%$ It is worth highlighting that hybrids Alva x CS-50, ITA90 x Antares, Alva x CD-403, DeltaOpal x ITA-96, DeltaOpal x IAC-22 and Alva x IAC-22 had positive heterosis estimates $(28.8 ; 29.5 ; 29.8 ; 31.4,33.0$ and $34.1 \%$, respectively).

\section{CONCLUSIONS}

Based on our results, the following conclusions were drawn:

1. Of the 14 traits evaluated, only three (fiber length, short-fiber index and reflectance) did not present variability among treatments.

2. Additive gene effects were predominant for all evaluated traits and only the Index of Production and Earliness showed a small component of the total genetic variability.

3. SCA was not significant for Picked Lint Percent or for any of the fiber traits analyzed.

4. Genotypes IAC-22, Antares, CD-403 and DeltaOpal contributed most to the increment of heterosis for most of the traits evaluated.

5. The hybrid combinations ITA-90 x Antares and DeltaOpal x IAC-22 are recommended for the improvement of seedcotton yield, lint yield, seed index and index of production and earliness.

\section{Análise dialélica entre cultivares de algodoeiro herbáceo}

RESUMO - Foram realizados todos os cruzamentos entre oito cultivares comerciais de algodoeiro, obtendo-se 28 combinações hibridas, que somados aos oito progenitores constituíram-se nos 36 tratamentos avaliados neste estudo. O ensaio experimental, em látice triplo 6 × 6, foi instalado em área do Curso de Agronomia, em 2000/01. Obtiveram-se dados das seguintes características agronômicas e de fibra: rendimento de algodão em caroço, peso de 100 sementes, porcentagem de fibras, rendimento de algodão em pluma, índice de produção e precocidade, indice micronaire, resistência e comprimento de fibras, uniformidade, indice de fibras curtas, elongação, indice de fiabilidade, grau de reflectância e grau de amarelecimento. Realizou-se a análise de variância univariada para todas essas variáveis, utilizando-se a metodologia proposta por Griffing (1956), método 4. Encontrou-se significância entre tratamentos e entre capacidades combinatórias. Houve predominância da ação gênica aditiva. Os valores heteróticos apresentaram sinais positivos e negativos, evidenciando o potencial das combinações híbridas para o melhoramento.

Palavras-chave: algodão, capacidade combinatória, heterose.

\section{REFERENCES}

Carvalho LP, Cruz CD and Moraes CF (1995) Diallel analysis of yield and other traits in cotton. Revista Brasileira de Genética 18: 93-97.

Cochran WG and Cox GM (1957) Experimental designs. $2^{\text {nd }}$ ed. New York, J. Wiley, 611p.

Costa JN, Freire EC and Santos JW (1977) Heterose e capacidade geral e especifica de combinacão em algodoeiro
Gossypium hirsutum L.. Revista de Oleaginosas e Fibrosas 2: $151-156$.

Coyle GC and Smith W (1997) Combining ability for within boll yield components in cotton, Gossypium hirsutum L. Crop Science 37: 1118-1122.

Cruz CD and Regazzi AJ (1997) Modelos biométricos aplicados ao melhoramento genético. $2^{\text {nd }}$ ed., Imprensa Universitária, Viçosa-MG, 390 p. 
PA Aguiar et al.

Griffing B (1956) Concept of general and specific combining ability in relation to diallel crossing systems. Australian Journal Science 9: 463-493.

Pedrosa MB, Freire EC, Costa JN and Andrade FP (2001) Estimativa das capacidades combinatórias em híbridos F1s de algodoeiro (Gossypium hirsutum L.) irrigado no Estado do Rio Grande do Norte. Revista de oleaginosas e fibrosas 5: 439-445.

Ramalho MAP, Santos JB and Zimmerman MJO (1993) Genética quantitativa em plantas autógamas; aplicações ao melhoramento do feijoeiro. Editora UFG, Goiânia, 271p.
Sprague GF and Tatum L (1942) A general vs. specific combining ability in single crosses of corn, Journal of the American Society of Agronomy 39: 923-932.

Sobral CAM, Silva FP, Melo FIO and Vieira FV (1991) Análise dialélica de caracteres agronômicos e morfológicos em algodão herbáceo. Anais do XXXVII Encontro Anual da Sociedade Brasileira de Genética, v. 14. p. 225-225.

Verma SS, Mehla AS, Lather BPS and Verma U (1988) Heterosis and combining ability studies in cotton, Gossypium arboreum L. Cotton Develop 17: 2-5. 